\section{Water stress and water wars}

\section{Frederic L. Pryor}

$I^{n}$

recent years, the conventional view expresses pessimism about the world's future freshwater availability. For instance, according to the United Nations Environment Program, "The world water cycle seems unlikely to be able to cope with the demands that will be made of it in the coming decades." Similar claims are made by others, such as Lester Brown and Sandra Postel. ${ }^{2}$ Alongside this view, an increased probability of war over this resource is predicted. Many cite approvingly a 1995 statement of a former W orld Bank vice president, Ismail Serageldin: "If the wars of this century were fought over oil, the wars of the next century will be fought over water." ${ }^{\prime 3}$ In this article I argue that if we look at the numbers, such pessimism is unwarranted and turns our attention from addressing some real problems concerning water and international conflict.

The conventional view argues that to accommodate a fast-growing world population and to reduce malnutrition, we will need to grow ever more food in the future. Although food production can be increased by expanding the land under cultivation, the additional arable land is becoming more scarce and increasing food production by more use of fertilizers, pesticides, and better seeds is reaching the point of diminishing returns. Although food production can also be increased through more irrigation, which played a major role in the higher productivity achieved through the "green revolution," we are also running into limits due to the rapidly rising expense of new dams and irrigation systems. To feed their population in the coming decades, countries will need more irrigation water and, therefore, wars over freshwater will become more frequent.

To develop more accurate ideas about water stress and water wars, three issues need examination: (1) Is there an impending shortage of freshwater? (2) Is there an impending food crisis because of water shortages? (3) Will future wars be triggered by water shortages? I argue that water-stress, according to conventional criteria, may become quite serious by 2025 , but this will not necessarily lead to either a food crisis or international war. ${ }^{4}$

Is there an unsustainable stress on freshwater?

How can we measure a water crisis?

Four initial caveats deserve mention: The data on the availability of freshwater in many countries are not very good, and the comparability of such data from country to country is limited. Projections of future water stress are fraught with even more perils, and long-term predictions have varied enormously. Moreover, endogenous effects of water stress, such as migration, are difficult to take into account. Finally, great uncertainties in projections arise because of possible impacts on the availability of freshwater due to climate changes arising from global warming and other factors. I must leave it to others to discuss the highly technical issues about climate change.

For this article several concepts used in the measurement of a stress on freshwater (a supply-side approach) need brief mention. Renewable water means merely that the water taken from lakes or the ground (including aquifers) does not result in a lowering of the water level of these sources. Freshwater includes all non-saline water. Few sources provide information on the purity of this water, so in this study we must consider all surface and ground water as fresh. A water withdrawal occurs when humans take water from rivers, lakes, or the ground, or collect it from rain. If freshwater is not recycled or reused by consumers, actual use is less because some usable water is lost through evaporation, runoff, or seepage along the way. In addition to water withdrawals, freshwater can be obtained through desalinization or by importation from other countries (shipping it on tankers, towing icebergs, etc.). Finally, water-stress arises when less freshwater for a jurisdiction is available than that indicated by conventional norms. This is different from a water scarcity which occurs when the demand for water at the current price is greater than the supply.

No single indicator gives a complete picture of a water stress. I use three supplyside measures for the physical availability of freshwater. ${ }^{6}$ Other more complex indicators are also available but they are difficult to interpret and supply few additional insights. First, the freshwater-availability indicator focuses on the per capita availability of renewable freshwater, including water from rivers in international river basins. ${ }^{7}$ Taking all uses of water into account, she designates nations with 1700 cubic meters per person per year of available water as having infrequent water shortages, 1000 cubic meters of water per person per year as being "relatively water-stressed," and 500 cubic meters or less per person per year or under as indicating a "chronic water scarcity." I use 1000 cubic meters per person per year (2740 liters per person per day) as one of my measures of water-stress. This indicator has the advantage that it is easy to calculate and understand. Combined with a population projection, it can also serve to approximate the per capita amount of freshwater available in the future, other than that obtained through desalinization or importation. At the same time it has several notable disadvantages. It approaches the problem from the supply side, measuring only renewable surface and groundwater flows, and does not take the demand side into account. It also says nothing about how 
Table 1: Countries projected to be water-stressed in 2025

Sub-Saharan Africa

Burkina Faso, Burundi, Cape Verde, Comoros, Djibouti, Eritrea, Ethiopia, Kenya, Malawi, Rwanda, Somalia, South Africa, Swaziland, Sudan

North Africa and Near East

Afghanistan, Algeria, Bahrain, Egypt, Iran, Iraq, Israel, Jordan, Kuwait, Lebanon, Libya, Mauritania, Morocco, Oman, Qatar, Saudi Arabia, Syria, Tunisia, U.A.E.,

Western Sahara, Y

Rest of Asia except former USSR

Maldives, India, Korea (South), Pakistan, Singapore

Europe, former USSR

Armenia, Azerbaijan, Belgium, Cyprus, Lithuania, Kazakhstan, Malta, Moldova, Portugal, Spain, Turkmenistan, Ukraine, Uzbekistan

North and South America, Oceania

Barbados, St. Kitts and Nevis, Peru

Note: The countries listed are deemed water-stressed by one or more of three criteria discussed in the text: water-availability (less than 1000 cubic meters per person per year), relative-water-stress (water withdrawals to water availability greater than 40 percent), or water-reliability (equal to four). Countries meeting these criteria for all three indicators are underlined. Data were not available for all three indices for the following countries: Barbados, Malta, St. Kitts and Nevis, and Western Sahara. The sources of data for the water-availability and relative-waterstress indices are discussed in note 6 . The water-vulnerability calculations come from Raskin, et al. (1997).

the freshwater is used and whether the potential availability of water is realized in an efficient manner which depends in part on the nation's infrastructure. For instance, in 2001 Israel had a renewable freshwater availability of about 198 cubic meters per person per year and yet it has been able to function as a modern nation by employing sophisticated water usage techniques. ${ }^{8}$

Second, the relative-water-stress indicator focuses on freshwater withdrawals. More specifically, it is the ratio of annual water withdrawals to the annual freshwater availability. High stress is considered to be a ratio of more than 40 percent; mediumhigh stress, from 30 to 40 percent; and medium stress, from 20 to 30 percent. These limits of course are arbitrary and accordingly a country such as Belgium is considered a nation of high water-stress even though its current ratio seems sustainable for the indefinite future. The relative-water-stress measure requires a projection of future water withdrawals, a calculation which, as indicated before, is not easy to make. The projections by Shiklomanov which I use here predict that on an aggregate basis water withdrawals will increase about 32 percent between 2000 and $2025 .^{9}$

Third, the water-reliability indicator has been calculated by Raskin and coworkers and is a composite of three separate measures: a measure of the ratio of water storage to water usage (this ratio takes into account the use of monsoon water in other parts of the year), a coefficient of variation of precipitation, and the dependency on water from an international river basin. ${ }^{10}$ Each of these three criteria is rated on a scale of one to four, running from no-stress to high-stress, and are added to form the combined index. For the analysis that follows, I select only those countries with an overall evaluation of "high-stress."

Water-stressed countries in 2025

Table 1 lists countries projected to be water-stressed in 2025 if they meet any one of the three discussed indicators. Several features of this listing deserve brief comment. First, as we would expect, the largest single block of water-stressed nations are in North Africa and the Near East. Second, a stricter definition of water-stress by any of the three criteria would reduce the number of listed countries. For instance, by defining stress, as measured by the water-availability index, to be 500 (rather than $1000)$ cubic meters per person per year, we would eliminate six nations from the list (Burkina Faso, Comoros, Eritrea, Ethiopia, Malawi, and Cyprus). Third, water-stress is exacerbated by high population growth. Of the 56 nations for which water-stress is predicted, 25 (44.6 percent) have a projected annual population growth of 1.5 percent. And forth, 30 nations (53.8 percent) in table 1 have 1.6 hectares of arable land per person or less.

Table 2 aggregates the data to provide a global perspective for 2025 and also presents several new indicators measuring personal access to freshwater. Using the criteria for water-stress from table 1, the data show that roughly one tenth of the world's population now live in water-stressed countries but that this figure will jump to about one-third by 2025 , estimates that accord with those of other researchers. ${ }^{11} \mathrm{~A}$ major factor underlying this increase is the inclusion of India among the waterstressed nations in 2025 , but not 2000 . If India were excluded from consideration, the increase in population living in water-stressed nations between 2000 and 2025 would be roughly seven percentage points and the problem of the increasing worldwide water stress would not seem so severe. ${ }^{12}$ China is not included among the waterstressed nations, but if North China were a separate nation, it would probably be water-stressed by the criteria discussed above and would have to be added to the totals.

Part A of table 2 suggests that, according to conventional criteria, a significant 
Table 2: Percentage of the world's population in countries with current or projected water-stress, 2000 and 2025

\section{A. Supply side}

- All countries with water-stress according

to any of the three criteria

- India alone (included as water-stressed

in 2025, but not in 2000)

- North China alone (China as a whole is not included as water-stressed)

\section{B. Demand side}

Countries with a low percentage of population having access to safe drinking water

- Less than 50 percent of population with

access to safe drinking water

- 50 to 75 percent of population with

access to safe drinking water

Countries with a low percentage of population having enough water for basic human requirements

- Less than 50 percent of population meeting

basic water needs

- 50 to 75 percent of population meeting

basic water needs

Sources for Part A: see note 9 and table 1. I have roughly estimated that the population in the water-stressed areas of north China numbered 200 million in 2000. According to Revenga, et al (1988) in the early 1980s the Yellow River basin had a population of 153 million, and I have projected the same population growth rate for this area as for the rest of the country (as estimated by the United Nations, 2003). Sources for Part B: Data on access to freshwater come from Gleick (2002, table 3) and WHO (2000); data on population meeting basic water requirements for human activities are from Gleick (1996). Since access to freshwater or to meet basic water needs depends on infrastructure investment, reliable projections cannot be made.

share of the world's population will be living in water-stressed countries in 2025 . As argued later on, however, this does not necessarily lead to food shortage given the enormous amount of fresh water that is wasted.

Part B of table 2 presents data on issues not yet discussed, namely, the share of the world's population in countries without access to safe drinking water and in countries without sufficient water for cooking, health, and other human purposes. In recen years "access" is defined as 20 liters per person per day from a source within one kilometer of the user's dwelling; "safe" is defined in terms of the technology used for obtaining the water, rather than by a direct measurement of its purity. Access to safe drinking water has of course obvious implications for health. The available data also show little correlation with the other indices of a water shortage on the supply side, and only three unfortunate countries, Oman, Qatar, and Yemen, reveal water stress on both the supply and demand indicators. A related indicator is the percentage of the population obtaining at least five liters per person per day which one expert roughly calculates is the minimum needed only for drinking, sanitation, washing, and other personal needs. ${ }^{13}$

These demand indicators do not necessarily measure a supply shortage, but rather poverty and the lack of suitable infrastructure to get available water to households Such measures are also a glaring sign of the failure of international assistance to help fulfil a vital development and health need.

Is there an impending world food shortage because of water stress?

Various economists and organizations dealing with agriculture and water have made sophisticated projections of the world's food supply in 2025. Rather than focus on the details of these forecasts, I will discuss the broad assumptions that underlie these predictions.

Food requirements

According to median projections of the United Nations, in 2025 and 2050 the world's population should be respectively 29 and 47 percent higher than in $2000 .^{14}$ If the composition of agricultural production remains the same, the value of food production must increase by at least these amounts for the global population to have the same per capita food consumption as in 2000. As per capita incomes rise, however, the composition of food production changes, primarily in a water-using direction. For instance, greater consumption of meat requires water for the animals, as well as for the crops they eat. As a generous guess, let us assume that this would increase the value of food production by one third, so that in 2025 , food production would have to increase 38.5 percent, not merely 29 percent.

Moreover, if we wish to reduce malnutrition in the world, then global food production must grow faster than the population. Various international organizations have estimated that between 14 and 21 percent of the world's population was undernourished in 2000. For the sake of safety let us assume the higher estimate and, arbitrarily, that these undernourished would need to consume 25 percent more food to achieve a proper diet. This means that world food production would have to 
increase by an additional 5.5 percent. Thus, to eliminate malnourishment by 2025 and to meet the rising food demand from a greater population and higher incomes, food production between 2000 and 2025 must increase 40.6 percent, or far less than half a percentage point per year.

Perspective can be gained by noting three facts. First, between 1975 and 2000, the annual total food production increased 2.3 percent a year. ${ }^{15}$ Second, over this period there was no sign of a deceleration of this average annual growth in food production. Third, as discussed later on in greater detail, during the same period land productivity (food per hectare of arable land) also increased rapidly and showed no sign of decelerating. For these reasons it should not be surprising that between 1970 and 2000 , the world price indices for food (and also for agriculture as a whole) fell considerably. ${ }^{16}$

\section{Arable land}

Between 1975 and 2000, arable land in use increased only 5.5 percent. For the same period a marked deceleration in the increase of arable land use is also apparent. ${ }^{17}$ Although land classified by the FAO as agricultural (but used for pasture, rangeland, and other non-crop purposes) is roughly 3.5 times greater in extent than arable land under use, much of it has quite low-quality soil. Most specialists seem to believe that the potential for intensive food production on such land is relatively low. It is not entirely clear how much of this low potential is due to previous use that degraded the soil, e.g., by wind and water erosion, and how much is due to naturally poor soil fertility and climatic conditions. Although rich agricultural lands are still being opened in some countries, such as Brazil, it is possible that the world's total crop lands will not be significantly greater in 2025 than in 2000 . This is due to problems associated with poor land or water management, such as erosion, water logging, salinization, or other oft-discussed farming problems

\section{Irrigated land}

The percentage of irrigated arable land in use increased from 11 percent in 1961 to 14 percent in 1975 and to 20 percent in $2000 .{ }^{18}$ Over this period, however, the annual increase was decelerating and, on a per capita basis, actually declined by a few percentage points. Four reasons suggest that the area under irrigation will not greatly increase. First, the cost of building irrigation dams is rising, in part because the most economical sites have already been used. Although the number of large dams (defined in terms of height and reservoir storage) which have served as one source of irrigation water increased ninefold between the end of World War II and the end of the twentieth century, dam construction hit a peak in the 1970s and, in the 1990s, fell drastically. ${ }^{19}$ At this point there were few large rivers left that have not already been controlled in this way. Second, these dams often carry high environmental, social, and economic costs. As a result of the Nasser Dam, for instance, considerable land in the lower Nile has lost fertility, and river fishing in the Nile delta has greatly suffered as well. Also, dam's capital and maintenance costs are seldom covered to a significant degree by fees for irrigation water. Third, higher energy costs often add considerably to the expense of irrigation. Fourth, salinization of irrigated land reduces land productivity. Roughly 20 percent of irrigated land is adversely affected by moderate or higher salinization, and another 4 percent of the non-irrigated land is similarly affected. ${ }^{20}$

A slow increase in irrigated land is, however, not catastrophic because the aggregate effect of irrigation on agricultural production is often highly overestimated. Of course, the relative productivity depends on local conditions, but for the world as a whole the FAO
Productivity-enhancing measures other than irrigation led to an increase in food production in the last quarter of the twentieth century between 60 and 64 percent. estimates that when total irrigated land was 16 percent of total arable land, it produced between 30 and 40 percent of the world's food. ${ }^{21}$ This suggests that, on an aggregated basis, irrigated land was 2.25 to 3.5 times more productive than nonirrigated land. If this average held between 1975 and 2000, the increase in irrigated land accounted for an increase in food production of somewhere between 6 and 10 percent. Taking into account the increase of arable land used in agriculture, such a calculation suggests that productivity-enhancing measures other than irrigation led to an increase in food production in the last quarter of the twentieth century between 60 and 64 percent.

If such productivity trends continue for the next quarter century, then even without an increase in irrigated land area more food than necessary will be produced, both to feed the growing world population at current standards and to eliminate malnourishment (if lack of crop production is the basic cause). Of course, some have questioned the underlying assumption about the increase in agricultural productivity They have suggested that crop yields are peaking and cannot go much higher. Some have even raised alarm about decelerating (or even declining) crop yields due to salinization and erosion. When using an index of total food production per hectare, I find no evidence of decelerating or declining land productivity in the 1975-2000 period. ${ }^{22}$ Decades of research on agriculture productivity for tropical areas have also begun to achieve a payoff, which should continue for some decades. In brief, the projected necessary increase in world food production does not seem to require the vast extension of irrigation with its concomitant demand for more water that occurred in the last quarter of the twentieth century. Rather, the rise in land productivity attributable to other factors such as better farming practices, better crops, and more efficient use of the currently available freshwater, may be more than sufficient.

This conclusion, however, focuses on food supply and demand for the entire 
world. In 2025, individual countries may of course produce less food than is necessary to feed their populations. This problem can be resolved by importing food, but such an economically efficient solution means that the goal of national food selfsufficiency must be scrapped, a price that some policymakers may find politically painful to pay, particularly for grains.

Will future wars be triggered by water shortages?

Some believe that gaining access to freshwater has been an important cause of past wars. In a study of 412 international crises for the period 1918-1994, however, Aaron Wolf finds only seven conflicts directly related to access to freshwater. ${ }^{23}$ Moreover, in three of these, no shots were fired. To assess directly the possibility of water wars, we must consider past experience carefully and look at the future in terms of possible water resource-based flashpoints for armed conflict in the various international river basins.

Possible lessons from past wars over water

A major difficulty in analyzing water wars arises from loose terminology. Words such as "conflict," "dispute," "tensions," "hostile actions," and "war" are often conflated. Moreover, water is sometimes only one of many factors leading to armed conflict between nations, so that it is often difficult to assess the importance of water per se as the cause of war. In the following discussion I distinguish between all-out wars with formal declarations from major military conflicts involving invasions and the use of heavy, military equipment and minor military conflicts involving military skirmishes and limited fighting. It must also be noted that he "record of acute conflict over international water resources is overwhelmed by the record of cooperation ... Furthermore, once cooperative water regimes are established through treaties, they turn out to be impressively resilient over time, even when between otherwise hostile riparians, and even as conflict is waged over other issues."24

Table 3 lists military engagements between countries that probably arose from disputes over water control in the last quarter of the twentieth century. It shows no instances of an all-out war over water, but this is partly a matter of interpretation. For instance, some analysts, such as Klare, argue that the Arab-Israeli war of 1967 "was largely triggered by fighting over control of the tributaries of the Jordan River." 25 When border or other issues were also involved, it is often difficult to determine whether water was the critical cause for armed conflict.

Several aspects of table 3 deserve note. First, in this period relatively few armed conflicts arose over the allocation of water, which accords with the general decline in inter-state warfare. ${ }^{26}$ Second, in five of the seven engagements that did occur, either one or both nations were water-stressed in 2000, according to at least one of the three criteria discussed earlier on (the two exceptions were the conflicts in the Orange and

\section{Table 3: Interstate military engagements over water, 1975-2000}

A. Wars listed by the International Peace Research Institute, Oslo (PRIO)

Cenepa

Peru-Ecuador

1995

Orange

South Africa-Lesotho

1998

Engagement near river; primarily a war over territory rather than a water dispute per se. PRIO lists this war with as one of "minor intensity" with probably less than 100 casualties.

South African troops occupied the Katse and Mohale dam areas when taking side in an internal Lesotho conflict. PRIO lists this entire conflict as one of "minor intensity" with slightly less than 120 deaths.

B. Other military engagements but not classified as interstate wars by PRIO

Tigris-Euphrates Iraq-Syria 1975

Tigris-Euphrates Iran-Iraq

1986

Karnaphauli

Bangladesh-India 1991

Kura-Araks Armenia-Azerbaijan 1992

Senegal Mali-Mauritania 1999

Notes: The river involved is listed on the top line of the first column, then the countries involved, and finally the date. This list excludes cases where the dispute did not escalate to use of military force but remained at the level of massing of troops and serious threats. The data on water disputes come from lists by Gleick (2004) and Wolf (n/d). The PRIO lists are found at PRIO (2005).

the Karnaphauli river basins). Third, armed conflicts over water were much more frequent in the previous quarter-century from 1950 through 1974. Nevertheless, if we exclude those that concerned the Jordan river basin and clashes between Israel and its neighbors in this period, the number of armed conflicts was roughly the same in the 
two twenty-five-year periods.

The relative infrequency of water wars suggests that from a cost/benefit perspective, the gains from armed conflicts over water are often dubious, especially when long-term expenses of occupation and costs of handling subsequent tensions are taken into account. Even when a powerful downstream nation simply destroys an upstream dam and then withdraws, this could have not only a severe short-term physical impact downstream but a costly long-term financial one, resulting from the loss of the upstream neighbor's cooperation in other areas and the necessity to maintain a large army. Such a cost/benefit calculation does not require a high degree of rationality. Buying water also seems less expensive in the long run that fighting wars and occupying other nations to obtain it

Future wars over water?

Some commentators argue that for wars over water, the past does not serve to predict the future. Consensus is lacking, however, on the critical conditions that would incite armed conflict over water resources. Klare notes that water shortages need not lead to conflict where states enjoy good relations with one another and have a history of resolving differences through peaceful negotiations. ${ }^{27}$ I might add that even enemies can cooperate over the allocation of water. ${ }^{28}$ Homer-Dixon argues on the basis of realpolitik that wars over river water between upstream and downstream neighbors are likely only under a narrow set of circumstances: "[T]he downstream country must be highly dependent on the water for its national well-being; the upstream country must be threatening to restrict substantially the river's flow; there must be a history of antagonism between the two countries; and, most important, the downstream country must believe that it is militarily stronger than the upstream country ... the situation is particularly dangerous if the downstream country also believes it has the military power to rectify the situation." ${ }^{29}$ In most, but not all of the cases reported in table 3, the downstream nation started the conflict.

Can we predict future wars over water? Current studies give conflicting results. For data covering the past 100 years or so, several researchers show that armed conflicts over water resulting in at least one death are significantly and positively related to variables such as autocratic regime type, the size of the river basin, and whether a major power is involved. Negative relations are established to variables such as years at peace, the level of economic development of the countries involved, and whether they are allied..$^{30}$ For purposes of prediction, objections can be raised because the barrier for defining armed conflict is low - certainly 25 deaths or less does not constitute a major war and, moreover, the definition of water stress is unsatisfactory. One set of researchers reaches conflicting conclusions on the basis of single variable correlations showing that no matter how it is measured, water stress is not a significant indicator of water disputes and, moreover, neither government type nor climate show any pattern of impact on water disputes. ${ }^{31}$ But since these correlations do not account for the effect of other variables, their use in predicting the future can be questioned. Hauge and Ellingsen present regression results showing that water-scarce countries are more likely to engage not only in international wars but also experience more domestic armed conflict when other risk factors such as high population density, income inequality, poverty, or non-democratic governments are added. $^{32}$ These international wars, however, may not necessarily be over water, which is the focus of this discussion.

Given such divergent results in predicting water wars based on regression studies, it seems more useful to employ a more transparent approach for looking at these issues. The starting point is a list of 261 international river basins which have been listed by Wolf and his associates. ${ }^{33}$ The first criterion for isolating the river basins most at risk of armed conflict is the institutional-physical approach. This focuses strictly on the role of water-stress as a potential cause of war. Starting with the list of countries predicted to be water-stressed in 2025 (table 1), I apply three criteria that would increase the probability of conflict: (a) that some countries in the international river basin will experience water-stress by 2025; (b) that a significant area of these water-stressed nations lies in the basin; and (c) that the water-basin area in these water-stressed nations covers a significant portion of the entire water basin. ${ }^{34}$ The fifteen water basins listed in the upper half of table 4 fit these three criteria. (Because of its size, table 4 is appended to this article.)

The second criterion for isolating river basins most at risk of armed conflict is the institutional-political approach which has been advanced in one way or another by a large number of political scientists. Rejecting the notion that water-stress will have much to do with future armed conflicts over water, they instead point to particular characteristics of the nations that might become involved in a military conflict. For instance, Bruce Russett concentrates on factors such as the degree of democracy in the countries involved, trade interdependency, military capability, alliances, and participation in international organizations. ${ }^{35}$ Other political scientists argue for other determinants of war. Few of them mention water issues. The most relevant empirical study in this genre which focuses on river basins is by Wolf, Yoffe, and Giordana. ${ }^{36}$ They argue that wars over water are more likely to be found in river basins with riparian nations unused to cooperating with each other (a situation intensified by a history of ethnic conflicts) and that lack the institutional capacity to coordinate their basin development projects such as dams or irrigation systems. They calculate the probability of war and, although they do not provide sufficient detail for others to replicate their results, I include in the lower half of table 4 their list of seventeen water basins where armed conflicts are most likely to occur.

It is noteworthy that with the exception of the Incomati, none of the river basins listed in the institutional-physical list (panel A) overlap with those in the institutionalpolitical list (panel B). Of the thirty-two basins, thirteen do not include any waterstressed nations and, of the remaining, eleven have never featured any conflict. To select those basins where armed conflict is most likely, a more systematic approach 
is needed and, for this purpose, I construct an index that contains three elements: ${ }^{37}$ the lack of past cooperation over water issues in the past; past conflicts (not necessarily leading to fatalities) over water; and geographical factors that increase or decrease the propensity of war. Since so few disputes over water issues have occurred in the past few decades (the period most relevant for making projections), the weights of these three factors can only be subjective, but since the relevant data are provided, readers may reweigh these factors as they please. The PACW index (propensity for armed conflict over water) is a ten-point scale running from 0 (no propensity) to 9 (high propensity) and is the sum of three components.

If we use a PACW score of 4.5 (the midpoint of the scale) or higher to indicate that future water-related interstate armed conflict is likely (by 2025) then only the Tigris-Euphrates, Han, and Salween basins qualify. If the trigger point is lowered to 3.5, then the list expands to include the Indus, Lempa, and Lake Turkana basins. Of these six, indicator B shows that armed conflict over water arose in the last quarter of the twentieth century in only two of them (the Indus and the Tigris-Euphrates). Since the Lempa and Salween basins do not include any water-stressed nations, they can be dropped from further discussion. Three of the remaining four river basins - the TigrisEuphrates, the Indus, and the Han - include countries where political tensions over a variety of issues, not just water, have been endemic in the last few decades. Whether disputes over water will serve as a flashpoint or merely as a contributing factor for armed conflict is difficult to say. The remaining river basin, Lake Turkana, did not experience armed conflict over water, although by 2025 one of the nations, Kenya, will be water stressed.

The number of probable loci for waterbased interstate conflict by 2025 are few and will probably not exceed those that occurred between 1975-2000. In contrast, intrastate armed conflict over water may increase.

Although this exercise does not allow exact predictions regarding the intensity of future water disputes in these basins, or whether armed conflict will erupt at all, it does suggest that the number of probable loci for water wars up to 2025 are few. These results also suggest that armed interstate conflict over water

will probably not be more frequent than they are today. Many commentators reject this kind of macro approach used above, and instead focus on micro issues that possibly might lead to armed conflict. Little agreement can be found among them, however. For instance, Sandra Postel sees five hot spots for serious water disputes: the Aral Sea region, and the Ganges, Jordan, Nile, and Tigris-Euphrates basins. ${ }^{38}$ Michael Klare focuses on four river basins: the Nile and the Tigris-Euphrates, where water allocation are the prime issue; and the Jordan and Indus, where water and a variety of political issues are intertwined.$^{39}$ For the Nile he emphasizes that Ethiopia, which had roughly the same population as Egypt in 2000, will have a third more than Egypt in 2050 and will be forced to use waters from the Blue Nile to feed its growing population, thus taking water away from Egypt. Homer-Dixon mentions only the Nile as a future trouble spot, claiming that the conditions for armed conflict will not exist for the Indus, Paraná, Euphrates, and Mekong rivers. ${ }^{40}$ DuPont, in contrast, claims that water cooperation among riparian nations in the Mekong basin is fragile (although he speaks of "considerable tensions" in the future rather than of armed conflict). ${ }^{41}$ Others mention potential conflicts over water between South Africa and its neighbors, or between Turkey and Syria or Iraq.

Whether or not states will be able to work out their differences without armed conflict, it is clear that costs of war over water usually outweigh the benefits, especially when there are many alternatives to war. In particular, the amount of freshwater available to a nation can be vastly increased by its more efficient use Agriculture now accounts for roughly 70 percent of water withdrawals in the world and currently less than half the water diverted for irrigation actually benefits crops. ${ }^{42}$ Moreover, effective water-usage techniques such as drip irrigation are available, so that even more water could be made available for other usage. For many purposes, waste water can also be reused. Waste of freshwater can also be reduced by better methods of pricing schedules. Finally, a variety of institutions have been created in the last few decades to mediate international disputes over water. ${ }^{43}$

\section{Conclusion}

I have presented evidence for three propositions. First, by 2025 a significant share of the world's population will be living in countries which are water-stressed, at least by conventional criteria. Since most countries have not yet utilized huge possibilities for water saving, however, the "stress" may have no large-scale negative impacts on agricultural production or the prospects for armed conflict. Second, macro-evidence suggests that the world will be able to feed its growing population, even as growth of food production through irrigation agriculture will not be as important in the first quarter of the twenty-first century as it was in the last quarter of the twentieth. Nevertheless, considerable investments in irrigation will still be necessary. Third, armed conflicts between nations have not been very frequent in the last quarter of the twentieth century and, although water stress is increasing, other conditions do not appear to be changing sufficiently to warrant the expectation that water wars will intensify in the next several decades. This expectation can be bolstered by the development of effective ways of conserving countries' available freshwater which reduce the temptation to appropriate water from a neighboring state, by the increasing effectiveness of new technical methods of monitoring water treaties, and by the increasing availability of institutions and methods for resolving disputes over water.

In brief, the evidence presented in this article suggests that in the coming decades the probability for interstate armed conflict over water is low. In contrast, localized water stress in nations with weak central governments water may increasingly lead to armed interstate civil disputes. These results suggest that direct efforts to prevent 
water conflicts, either external or domestic, are misguided. Rather, efforts should be focused on reducing water wastage, increasing water recycling, rational pricing of water (to reduce demand), and on breaking down barriers to trade in food (so that water from water-rich regions can be "transported" via food trade to water-poor regions). In some cases considerable resources will be necessary, e.g., lining irrigation channels to reduce seepage. In other cases, imaginative policy measures must be undertaken, e.g., eliminating the crazy-quilt of water rights in California which leads to irrational water usages. In the long run, however, such measures will most likely be considerably less expensive for all parties involved than armed water conflicts.

\section{Notes}

Frederic L. Pryor is Professor of Economics at Swarthmore College, Pennsylvania and may be reached at fpryor1@swarthmore.edu. This article is a condensed version of Pryor (2006). The extended version presents a great deal more of the documentation supporting the analysis as well as a discussion of additional views on the various issues. I thank Jurgen Brauer, Raymond Hopkins, Zora Pryor, Bruce Russett, and Victoria Wilson-Schwartz for comments on an earlier draft.

\section{UNEP, 2001.}

2. See, e.g., Postel (1999) and Brown (2005).

3. The statement was made in Stockholm in August 1995 and repeats a sentiment common in Egypt at that time. In personal communication with the author, however, Serageldin complained that few of the hundreds citing this quotation include the remainder of his sentence: “... unless we change our approach to managing this precious and vital resource."

4. Small-scale conflicts over water appears to occur more often within a country, rather than between nations, e.g., disputes over dam building in India, pollution or dessication of many inland lakes, the devastation of the Aral Sea, etc. To limit the length of this essay, however, I focus only on international disputes.

5. See, e.g., Alcamo and Henrichs (2002).

6. Data on water availability come from Gleick (2004,pp. 257-262) and refer to 2000 or the closest year that could be obtained. Population data are for 2000 and come from the United Nations (2003), supplemented by data from the U.S. Census Bureau (2004). No data are available for the Western Sahara, but it is listed on the basis of qualitative evidence. Projections of the renewable water availability index are made with the assumption that freshwater availability remains the same as in 2000 .
Projections of water withdrawals for 79 nations up to 2025 come from Shiklomanov (1998), adjusted for more recent population estimates. For other countries I have based the estimates on Shiklomanov's regional estimates. For more details, see Pryor (2006).

7. See Falkenmark (1989).

8. See Gleick (2004, p. 261).

9. Gleick (2000, p. 59) reports nine forecasts made between 1995 and 2000 of global water use (or withdrawals) in 2025; they ranged from 3635 to 5500 cubic kilometers. For better or worse, I use the Shiklomanov estimates which fall roughly in the middle of the most recent extrapolations under "business-as-usual" scenarios. An interesting alternative measure to the relative-water-stress index is the ratio of the groundwater removed to the estimated groundwater recharged. Such a measure summarizes the change in the water table of a nation. It is, however, difficult to estimate and is available for only a limited number of nations.

10. See Raskin, et al. (1997).

11. See, e.g., Seckler, et al. (1998).

12. Unfortunately, an indicator of water reliability is not available for 2050 . Calculated with only two measures, the water-availability and relative-water stress indicators, the share of the global population in water-stressed nations increases only 3 percentage points between 2025 and 2050 .

13. Gleick (1996). This is about double the amount necessary for survival, as calculated by others; it also does not include other uses for water such as agriculture.

\section{United Nations (2003).}

\section{FAOStat (2005).}

16. World Bank (2005, table 6.4).

\section{FAOStat (2005).}

\section{FAOStat (2005).}

19. World Commission on Dams (2000, p. 9). 


\section{Gleick (2000, p. 269).}

21. FAO (1993, chapter 1).

22. Or, for that matter, in the 1961-2002 period. Calculated from FAOStat (2005).

23. Wolf (1997).

24. Wolf, et al. (2003, p. 30).

25. Klare, 2001, p. 139.

26. Gleditsch, et al. (2002).

27. Klare (2001, p. 139).

28. W ater disputes can be peacefully resolved, even between unfriendly countries. For instance, Israel and Jordan were hostile for many years, but the two countries held secret negotiations to cooperate over water during the period. Their water treaty of 1994 covered not only the allocation of the waters from the Jordan and Yarmouk Rivers but also the Araba/Arava groundwater aquifer and the contamination of these joint water resources. Although India and Pakistan fought two wars, the Indus River Commission survived these conflicts and its members cooperated over water issues (Wolf, et al., 2003).

29. Homer-Dixon (1999).

30. Toset, et al. (2000), Furlong and Gleditsch (2003), and Gleditsch, et al. (2004).

31. Wolf, et al. (2003).

32. Hauge and Ellingsen (1998).

33. Wolf, et al. (1999).

34. More specifically: (a) the countries must be listed in table 1; (b) at least 10 percent of the land mass of each country must be located in the water basis; (c) at least 10 percent of the land area of the basin is located within the borders of these water-scarce countries.

35. Russett (2006).
36. Wolf, Yoffe, and Giordana (2003).

37. The construction of the described in detail in Pryor (2006).

38. Postel (1999, chapter 7).

39. Klare (2001).

40. Homer-Dixon (1999).

41. DuPont (2001, pp. 126-130).

42. Postel (1993).

43. These alternatives are discussed in much greater detail in Pryor (2006).

\section{References}

Alcamo, Joseph and Thomas Henrichs. 2002. "Critical Regions: A Model-Based Estimation of World Water Resources Sensitive to Global Changes." Aquatic Sciences Vol. 64, No. 4, pp. 352-362.

Brown, Lester. 2005. “A Planet under Stress,” pp. 37-51 in John S. Dryzek and David Schlosberg (eds.) Debating the Earth. New York: Oxford University Press.

Dupont, Alan. 2001. East Asia Imperilled: Transnational Challenges to Security. New York: Cambridge University Press.

Falkenmark, Malin. 1989. "The Massive Water Scarcity Now Threatens Africa." Ambio Vol. 18, No. 4, pp. 268-275.

Food and Agricultural Organization (FAO). 1993. The State of Food and Agriculture 1993. Rome: FAO

Food and Agricultural Organization (FAO). FAOStat. $<$ http://faostat.fao.org/foastat/collections?subset=agriculture $>$ [accessed 4 October 2005]. Note that the current site $<$ http://faostat.fao.org/default.aspx $>$ [accessed 4 August 2006] no longer contains all the information cited in the text.

Furlong, Kathryn and Nils Petter Gleditsch. 2003. "Geographic Opportunity and Neomalthusian Willingness: Boundaries, Shared Rivers, and Conflict. "Paper presented at European Consortium for Political Research Workshop.

Gleditsch, Nils Petter, Peter W allensteen, Mikael Erikson, Margareta Sollenberg, and Håvard Strand. 2002. "Armed Conflict 1946-2001: A New Dataset.” Journal of Peace Research Vol. 39, No. 5, pp. 515-539.

Gleditsch, Nils Petter, Taylor Owen, Kathryn Furlong, and Bethany Lacina. 2004. "Conflicts over Shared Rivers: Resource Wars or Fuzzy Boundaries." Paper presented to the Convention of International Studies Association, Montreal. 
Gleick, Peter H. 1996. "Basic Water Requirements for Human Activities: Meeting Basic Needs." Water International Vol. 21, No. 1, pp. 83-92.

Gleick, Peter H., ed. 2000. The World's Water, 2000-2001. Washington, DC: Island Press.

Gleick, Peter H., ed. 2002. The World's Water, 2002-2003. Washington, DC: Island Press.

Gleick, Peter H., ed. 2004. The World's Water, 2004-2005. Washington, DC: Island Press.

Hauge, Wenche, and Tanja Ellingsen. 1998. "Beyond Enviornmental Scarcity: Causal Pathways to Conflict.” Journal of Peace Research Vol. 35, No. 3, pp. 299-317.

Homer-Dixon, Thomas F. 1999. Environment, Scarcity, and Violence. Princeton, NJ: Princeton University Press.

Klare, Michael T. 2001. Resource Wars: The New Landscape of Global Conflict. New York: Metropolitan Books.

Postel, Sandra. 1993. "Water and Agriculture," pp. 56-67 in Peter Gleick (ed.) Water in Crisis: Guide to the World's Fresh Water Resources. New York: Oxford University Press.

Postel, Sandra. 1999. Pillar of Sand: Can the Irrigation Miracle Last? New York: W.W. Norton.

[PRIO] Peace Research Institute, Olso. "The PRIO/Uppsala Armed Conflict Database, version 3-2005b." Released 6 September 2005. Available online at $<$ www.prio.no/page/CSCW/ research detail/Programme detail_CSCW/9649/ 45925.html $>$. [accessed 4 August 2006].

Pryor, Frederic L. 2006. "W ater Stress and Water Wars." Background paper. $<$ http://www.swarthmore.edu/SocSci/Economics/fpryor1/WaterEssay.pdf $>$ [accessed 4 August 2006].

Raskin, Paul, et al. 1997. Comprehensive Assessment of the Freshwater Resources of the World. Stockholm: Stockholm Environmental Institute.

Ravenga, Carmen, Siobhan Murray, Janet Abramovitz, and Allen Hammond. 1988. Watersheds of the World: Econological Value and Vulnerability. Washington, DC: Worldwatch Institute.

Russett, Bruce. 2006. Purpose and Policy in the Global Community. New York: Palgrave-Macmillan.

Seckler, David, Upali Amarasinghe, David Molden, Rhadika de Silva, and Randolph Barker 1998. World Water Demand and Supply, 1990 to 2025: Scenarios and Issues. International Water Management Institute. Research Report 19. Colombo, Sri Lanka: International Water Management Institute. $<$ http://www.iwmi.cgiar.org/pubs/PUB019/RR019.htm> [accessed 4 August 2006].

Shiklomanov, Igor A. 1998. "Summary of the Monograph "World Water Resources at the Beginning of the $21^{\text {st }}$ Century" Prepared in the Framework of IHP UNESCO." [IHP: International Hydrological Programme]
$<$ http://webworld.unesco.org/water/ihp/db/shiklomanov/summary/html/ summary.html\#Conclusion $>$ and

$<$ http://webworld.unesco.org/water/ihp/db/shiklomanov/part'3/ Read'me.html $>$ [accessed 24 September 2005]

Toset, Hans-Petter Wollegaek, Nils Petter Gleditsch, and Håvard Hegre. 2000 "Shared Rivers and Interstate Conflict." Political Geography Vol. 19, No. 6, pp 971-996.

United Nations. 2003. World Population Prospects: The 2002 Revisions. Vol 1. New York: United Nations.

[UNEP] United Nations Environment Programme. 2001. Global Environment Outlook (GEO) 2000. <www.grida.no/geo2000/english/0236.htm> [accessed 4 August 2006].

U.S. Department of Commerce, Census Bureau. 2004. Global Population at a Glance: 2002 and Beyond. International Population Reports, No. 02/1. Washington, DC: U.S. Department of Commerce.

Wolf, Aaron T. n/d. "International Water Events Database, 1948-1999." $<$ www.transboundarywaters.orst.edu/projects/events/> [accessed 4 August 2006]

Wolf, Aaron T. 1997. “Water Wars' and Water Reality: Conflict and Cooperation Along International Waterways," pp. 251-265 in S.C. Lonergan, ed. Environmental Change, Adaption, and Security. Boston: Kluwer.

Wolf, Aaron T., Jeffrey A. Natharius, Jeffrey J. Danielson, Brian S. W ard, and Jan K. Pender. 1999. "International River Basins of the W orld." International Journal of Water Resources Development Vol. 115, No. 4, pp. 387-427.

Wolf, Aaron T., Shira B. Yoffe, and Mark Giordano. 2003. "International Waters Identifying Basins at Risk.” Water Policy Vol. 5, No. 1, pp. 29-60.

World Bank. 2005. World Development Indicators. W ashington, DC: World Bank. WCD (World Commission on Dams). 2000. Dams and Development: A New Framework for Decision-Making. London: Earthscan Publications.

World Health Organization (WHO). 2000. Global Water Supply and Sanitation. Assessment 2000 Report. <www.who.int/docstore/water_sanitation_health/ Globassessment/GlobalTOC.htm $>$ [accessed 4 August 2006]. 
(C) www.epsjournal.org.uk - Vol. 2, No. 2 (2007)

\section{Table 4: International river basins with a potential for armed conflict over water}

River basin

Water-stressed countries

in the basin

$\underline{\text { A. Institutional-physical approach }}$

\section{Africa}

Awash

Incomati

Juba-Shibeli

Lake Turkana

Maputo

Nile

Asia

Aral Sea basin

Indus

Jordan

Tigris-Euphrates

Djibouti, Ethiopia, Somalia

South Africa, Swaziland

Ethiopia, Kenya, Somalia

Ethiopia, Kenya, Sudan

South Africa, Swaziland

Burundi, Egypt, Eritrea, Ethiopia,

Kenya, Rwanda, Sudan

$\underline{\text { Kazakhstan, Turkmenistan, Uzbekistan }}$ India, Pakistan

Iran, Iraq, Jordan, Saudi Arabia, Syria

Moldova, Romania

Moldova, Ukraine

Portugal, Spain

Portugal, Spain

Portugal, Spain

Guadiana

Tegus/Tejo
Egypt, Israel, Jordan, Lebanon, Syria

Non-water-stressed countries

in the basin

$\underline{\text { Mozambique }}$

Uganda

Mozambique

Congo (Zaire), Tanzania, Uganda

Kyrgyzstan, Tajikistan, China

Afghanistan, China

Turkey

15 nations including Hungary,

Serbia, Austria, and Germany

Poland

$-$

(Table 4 continued on next page.)

$\begin{array}{llll}\text { Indicator } & & \text { PACW score } \\ A & B & C & (0-9)\end{array}$

(0-9)

$\begin{array}{llll}3.0 & 0.0 & 0.0 & 3.0 \\ 1.5 & 0.0 & 0.0 & 1.5 \\ 2.0 & 0.0 & 0.5 & 2.5 \\ 3.0 & 0.0 & 05 & 3.5 \\ 2.0 & 0.0 & 0.0 & 2.0 \\ 0.5 & 0.5 & 1.0 & 2.0\end{array}$

$\begin{array}{llll}2.5 & 0.2 & 0.0 & 2.7\end{array}$

$\begin{array}{lll}1.5 & 0.1 & 2.0\end{array}$

$\begin{array}{llll}0.0 & 0.3 & 0.5 & 0.8\end{array}$

$\begin{array}{llll}2.5 & 2.0 & 1.5 & 6.0\end{array}$

$\begin{array}{llll}0.5 & 1.6 & 0.0 & 2.1\end{array}$

$\begin{array}{llll}1.0 & 0.0 & 0.0 & 1.0\end{array}$

$\begin{array}{llll}0.5 & 0.0 & 0.0 & 0.5\end{array}$

$\begin{array}{llll}0.5 & 0.0 & 0.0 & 0.5\end{array}$


(C) www.epsjournal.org.uk - Vol. 2, No. 2 (2007)

\section{Table 4 (continued)}

\section{B. Institutional-political approach: Wolf-Yoffe-Giordano (2003, p. 52)}

\section{Africa}

Incomati

Kunene

Lake Chad Algeria, Sudan, Libya

Limpopo

Okavango

Orange

Senegal

Zambezi

\section{Asia}

Ganges-Brahmaputra

Han

Kura-Araks

Mekong

$\mathrm{Ob}$

Salween

Tumen

Americas

La Plata

Lempa
India, Bangladesh

Korea (South)

Armenia, Azerbaijan, Iran

$-$

$-$
South Africa, Mozambique, Swaziland

Angola, Namibia

C.A.R., $\underline{\text { Cameroon, }}$ Chad, Niger, Nigeria

Botswana, Mozambique, South Africa,

Zimbabwe

Angola, Botswana, Namibia, Zimbabwe $\quad \begin{array}{lllll}2.5 & 0.0 & 0.0 & 2.5\end{array}$

Botswana, L

Guinea, Mali, Mauritania, Senegal 1.0

Angola, Botswana, Congo (Zaire), Malawi, 2.0

Mozambique, Namibia, Tanzania, Zambia,

Zimbabwe

Bhutan, China, Myanmar, Nepal

Korea (North)

Georgia, Russia, Turkey

Cambodia, China, Laos, Myanmar,

Thailand, Vietnam

China, Kazakhstan, Russia

China, Myanmar, Thailand

China, Korea (North), Russia

Argentina, Bolivia, Brazil, Paraguay,

Uruguay

El Salvador, Guatemala, Honduras

$\begin{array}{llll}0.5 & 0.2 & 1.0 & 1.7\end{array}$

3.0

1.5

$\begin{array}{llll}2.0 & 0.0 & 0.0 & 2.0 \\ 1.5 & 1.0 & 0.0 & 2.5 \\ 1.0 & 0.0 & 0.5 & 1.5 \\ 2.0 & 0.0 & 0.0 & 2.0 \\ & & & \\ 2.5 & 0.0 & 0.0 & 2.5 \\ 2.0 & 0.9 & 0.0 & 2.9 \\ 1.0 & 0.3 & 0.5 & 1.8 \\ 2.0 & 0.5 & 0.0 & 2.5\end{array}$

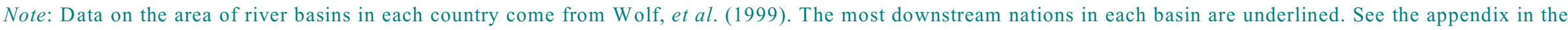
extended paper at Pryor (2006) for the definitions of the components of the PACW (propensity-for-armed conflict over water) index and how it is computed. 